Prace Literackie LVIII

Wrocław 2018

https://doi.org/10.19195/0079-4767.58.25

JUSTYNA BAJDA

ORCID: 0000-0001-7402-090X

Uniwersytet Wrocławski

\title{
Między studium a punctum. Spotkania ze sztuką w poetyckiej twórczości Stanisława Ledóchowskiego
}

Od kilku dekad daje się zauważyć szczególne zainteresowanie literaturoznawców oraz historyków sztuki ekfrazą (gr. ékphrasis) rozumianą jako jedna z deskryptywnych form literackich bądź jako samodzielny gatunek opisujący dzieło sztuki. Geneza pojęcia wiązana jest $\mathrm{z}$ czasami drugiej retoryki ${ }^{1}$, choć, jak podkreśla Marek Skwara, ,już wtedy istniały co do jej statusu wątpliwości, traktowano ją jako kategorię, jeden z rodzajów opisu, topos, figurę retoryczną, dopuszczano także możliwość stworzenia z niej samodzielnego gatunku"2. Współczesne rozważania także nie przynoszą jednoznacznych ustaleńn ${ }^{3}$. W badaniach nad wierszami o sztuce pojawiają się odmiany i podtypy ekfraz, przywoływana jest

${ }^{1}$ Por. R. Popowski, Wstęp, [w:] Filostrat Starszy, Obrazy, przekł., kom. i przyp. R. Popowski, Warszawa 2004, s. 13-88.

${ }^{2}$ M. Skwara, O niektórych właściwościach ekfrazy. Na przyktadzie poetyckich recepcji Szału uniesień Władystawa Podkowińskiego w wybranych utworach młodopolskich i nie tylko, [w:] Perspektywy polskiej retoryki, red. B. Sobczak, H. Zgółkowa, Poznań 2007, s. 194.

${ }^{3}$ Na przykład rozważania Adama Dziadka (ekfraza — gatunek) i Małgorzaty Czermińskiej (ekfraza - figura retoryczna); por. między innymi: A. Dziadek, Problem Ekphrasis - dwa Widoki Delft (Adam Czerniawski i Adam Zagajewski), „Teksty Drugie” 2000, z. 4 (63), s. 141-152; idem, Obraz jako interpretant. Na przykładzie polskiej poezji wspótczesnej, „Pamiętnik Literacki” 92, 2001, z. 2, s. 127-148; idem, Obrazy $i$ wiersze. Z zagadnień interferencji sztuk $w$ polskiej poezji współczesnej, Katowice 2004; M. Czermińska, Ekfrazy w poezji Wisławy Szymborskiej, „Teksty Drugie" 2003, nr 2-3, s. 230-242; eadem, Gotyk i pisarze. Topika opisu katedry, Gdańsk 2003. Por. także inne wybrane opracowania teoretyczno- i historycznoliterackie (w układzie chronologicznym), między innymi: R. Cieślak, Oko poety. Poezja Tadeusza Różewicza wobec sztuk wizualnych, Gdańsk 1999; S. Wysłouch, Literatura i semiotyka, Warszawa 2001; J. Łukasiewicz, Grochowiak i obrazy, Wrocław 2002; Interakcja sztuk: literatura, malarstwo, ekfraza, red. D. Heck, Wrocław 2008; A. Grodecka, Wiersze o obrazach. Studium z dziejów ekfrazy, Poznań 2009; eadem, Stowo i obraz w epoce multiplikacji, Poznań 2016. 
szeroko rozumiana kategoria ekfrastyczności, pisze się o poetyckich spotkaniach z dziełem sztuki. Kwestie te analizował (odwołując się do wcześniejszych ustaleń Michała P. Markowskiego ${ }^{4}$ ) Paweł Gogler, wskazując możliwość podziału na ekfrazę „właściwą” (klasyczną, odsyłającą do starożytnych kanonów opisowych i wizualizacyjnych) oraz ekfrazę „współczesną” (odchodzącą od założeń wzorca retorycznego). Rozważania autora prowadzą do konkluzji o znaczeniu istniejącego we współczesnej poezji rozdziału opisowości od interpretacji, a przede wszystkim o istocie poszukiwań w dziele sztuki impulsów stających się dla transponującego je na mowę wiązaną poety pretekstem do wpisania artefaktu w szeroki kontekst kulturowy, filozoficzny bądź historyczny:

Gra nie idzie już bowiem o wierność wobec malarskiego pierwowzoru i taką werbalizację, by dzieło stanęło przed oczyma, co oznaczałoby, że poezja próbuje zastąpić czy przewyższyć malarstwo. Idzie o moc tekstotwórczą, o przetworzenie obrazu, często o jawne poszukiwanie w dawnych dziełach jakiegoś sensu, który w wierszu można poddać próbie. Wnioski z tych rozważań nieubłaganie prowadzą do przejścia od opisu ku sprawom interpretacji, problemom egzystencjalnym, filozoficznym, gdyż malarstwo w literaturze zmieniło swą funkcję. Sama poezja coraz częściej staje się świadectwem poczynań hermeneutycznych, które określa się mianem „spotkania z obrazem” jako jedną z perspektyw naszego bycia-w-świecie. I przy tym wspólnym dla wielu poetów obszarze najbardziej chyba interesujące jest, jakie znaczenie ma owo „spotkanie z obrazem” dla każdego z nich i jak przy wszystkich, niepowtarzalnych różnicach poeta poprzez język nawiązuje do tradycji, jak re-interpretuje sztukę, jaką funkcję pełni ona w jego poezji ${ }^{5}$.

Można przyjąć, że ,jakiś sens” dzieła sztuki, o którym pisze Gogler, staje się dla poety swoistym punctum $^{6}$, na które instynktownie reaguje słowem, intymnym spotkaniem poświadczającym nie tylko jego erudycję i określoną świadomość estetyczną, ale też (a może nawet przede wszystkim) indywidualną wrażliwość. Odwołanie do kategorii Rolanda Barthes'a pozwala na wyeksponowanie roli indywidualnego spotkania poety $\mathrm{z}$ artefaktem, jego osobistego zachwytu i jednostkowych odkryć miejsc, które następnie utrwali w słowie. „Poruszenie”, o którym pisze Barthes, analizując fotografię, jest przecież dane także poecie, gdy stając przed dziełem sztuki, najpierw jest konfrontowany z kulturowym studium dzieła (teoretycznie dostępnym wszystkim odbiorcom), żeby potem zostać dosięgniętym (jeżeli będzie mu to dane) przez wyjątkowe punctum obrazu czy rzeźby. Czytamy u Barthes'a:

To za pośrednictwem studium interesuję się wieloma zdjęciami, bądź odbierając je jako świadectwa polityczne, bądź smakując jak dobre obrazy historyczne. Gdyż to właśnie poprzez kulturę (to znaczenie jest obecne w studium), uczestniczę w wyrazie twarzy, gestach, realiach, działaniach.

Drugi element przelamuje studium lub poddaje je rytmowi. Tym razem to nie ja go szukam (ponieważ moja świadomość zajmuje się polem studium), to on wybiega ze sceny jak strzała i prze-

${ }^{4}$ M.P. Markowski, Ekphrasis. Uwagi bibliograficzne z dołaczeniem krótkiego komentarza, „Pamiętnik Literacki” 90, 1999, z. 2, s. 229-236.

5 P. Gogler, Kłopoty z ekfraza, „Przestrzenie Teorii” 2004, nr 3-4, s. 152.

${ }^{6}$ Por. R. Barthes, Światto obrazu. Uwagi o fotografii, przeł. J. Trznadel, Warszawa 2008. 
szywa mnie. [...] Dlatego ten drugi element, który narusza studium, nazwę punctum; albowiem punctum to także użądlenie, dziurka, plamka, małe przejęcie — ale również rzut kośćmi ${ }^{7}$.

To nie powszechnie rozpoznawalne studium (nawet najbardziej interesujące i wymagające szerokiej świadomości historycznej, politycznej czy ogólnokulturowej) stanie się impulsem do osobistego spotkania poety ze sztuką, lecz właśnie owo niepowtarzalne punctum. Dzięki niemu Barthes mógł w najprostszych słowach oddać istotę swojego jednorazowego zderzenia z siłą fotografii: „To zdjęcie porusza mnie, inne nie"». Należy jednak pamiętać o zasadniczej różnicy między punctum, które odnajduje Barthes na fotografii, a tym celującym w nas podczas spotkania z obrazem czy rzeźbą. Barthes wyraźnie pisze o „przypadkowości” kompozycji fotografii (głównie reportażowej) oraz o niezamierzonym zaistnieniu - nawet na zdjęciu pozowanym - elementów, które później mogą się stać dla odbiorcy punctum. W wypadku dzieła sztuki nie mamy do czynienia z efektem „rzutu kośćmi” (choć czy zawsze?), ale nie oznacza to, że każdy odbiorca musi je postrzegać w taki sam sposób. Poetycka ekfraza przestaje być jedynie kolejną reprezentacją rzeczywistości, staje się intymną odsłoną poety, spotkaniem z sensem odkrytym i odczuwanym tylko przez niego.

\section{Musée imaginaire}

Stanisław Ledóchowski — rzeźbiarz (warszawska ASP), krytyk sztuki i dziennikarz prasowy i radiowy, scenograf, kolekcjoner, bibliofil, badacz przeszłości ${ }^{9}$. To także poeta, którego wiersze z tomu Liście od Krakowa $(2013)^{10}$ Anna Mickiewicz umieszcza głównie w obrębie poezji historycznej, gatunku, który, jak pisze autorka, „praktycznie nie istnieje w dzisiejszym kręgu zainteresowań badaczy współczesnej literatury pięknej"11:

Poeta doskonale zna fakty, zaklina słowem czas poetycko-historyczny. Słowu poświęcił swój krótki esej rozpoczynający tomik. Jest mu wierny, w swych wierszach nadając mu nowy sens. Słowo uważa za najważniejszy fragment poezji. Dzięki niemu wprowadza nas w krainę zaczarowanych dawnych wspomnień postaci, miejsc i wielkich osobowości. Słowo odkrywa ich przeszłość, zatrzymuje na chwilę, daje się nasycić wspomnieniom osobistym związanym z Krakowem. Zanurzamy się

${ }^{7}$ Ibidem, s. 51-52.

8 Ibidem, s. 39.

9 Stanisław Ledóchowski współpracował między innymi z pismami: „Współczesność” (współzałożyciel tygodnika), „Kierunki”, „Przegląd Kulturalny”, „Kultura”, „Kolekcjoner Polski” (redaktor miesięcznika), oraz z redakcją literacką Polskiego Radia. Jest autorem dekoracji i rekwizytów do wielu filmów, między innymi (chronologicznie): Trzecia część nocy (1971, reż. A. Żuławski); Diabet (1972, premiera: 1988, reż. A. Żuławski); Pryzmat (1975, reż. K. Karabasz); Gdziekolwiek jesteś, panie prezydencie (1978, reż. A. Trzos-Rastawiecki); Na srebrnym globie (1987, reż. A. Żuławski). Właściciel bezcennych zbiorów związanych z biografią i twórczością Juliusza Słowackiego oraz z Liceum Krzemienieckim (obecnie depozyt w Muzeum Romantyzmu w Opinogórze).

10 S. Ledóchowski, Liście od Krakowa, Warszawa 2013.

${ }^{11}$ A.M. Mickiewicz, Stanisław Ledóchowski, [w:] D. Błaszak, A.M. Mickiewicz, Kosmos literatów, Orlando 2018, s. 249. 
wraz z nim w prawie bajkowy świat miasta, odwiedzamy zakątki, zapomniane uliczki, które stają się dzięki pięknemu słowu bliskie i znajome. Wije się ono, wraz z czasem tworząc meandry historii zanurzonej w naturze, do której autor też przywiązuje dużą rolę. [...] To poezja wielce emocjonalna, nasycona sentymentalizmem do przeszłości kraju i przeszłości osobistej. Czytając, zastygamy w słowach i czasach odległych, z nutą tkliwości i zadumy. W miejscach, gdzie nas nie było i nie będzie, gdyż taka jest kolej losu ${ }^{12}$.

Charakteryzując przestrzeń wierszy Ledóchowskiego, Mickiewicz wskazuje na faktografię, detaliczność i peregrynacyjny charakter spotkań z elementami otaczającej podmiot rzeczywistości, podkreśla też rolę wszechobecnej w tej poezji pamięci i sentymentalnego odbioru świata. Trudno z tym się nie zgodzić, choć tak zasadnicza ocena poezji Ledóchowskiego świadczyłaby o jej jednowymiarowości, skupieniu się na opisie faktów, tworzeniu narracji osnutych jedynie na odwołaniach do historycznych postaci i wydarzeń, budowaniu paraleli między przeszłością a osobistymi przeżyciami. Nie do końca tak jest. Spotkania Ledóchowskiego z historią rzeczywiście są spotkaniami bardzo intymnymi, w których odnajduje się potrzebę utożsamienia z miejscem i ślad pamięci narodu, miasta, rodu, ale odczuwa się w nich także zmysłową wrażliwość i emocjonalność artysty. Czas miniony przywoływany jest często jako tło spotkania ze sztuką, a może raczej: chwila, która jest już historią, staje się częścią sztuki. Pamięć miejsca i ludzi dosłownie wydobywana jest z pojedynczych kamieni budowli, marmurowych rzeźb, płócien mistrzów.

Dzieła plastyczne pojawiają się też w wierszach spoza tomu Liście od Krakowa. Ledóchowski, członek Towarzystwa Bibliofilów Polskich ${ }^{13}$, ma na swoim koncie bibliofilskie wydania pojedynczych utworów, nawiązujące tradycją do dziewiętnastowiecznych i międzywojennych poczynań miłośników książki pięknej ${ }^{14}$. Znalazły się wśród nich także kolejne spotkania autora ze sztuką.

Ikonosfera Ledóchowskiego była budowana latami. Poeta dokonywał świadomych wyborów dyktowanych przez pamięć przestrzeni, miejsc, ludzi (to płasz-

12 Ibidem, s. 249-250.

13 Towarzystwo Bibliofilów Polskich powstało w 1921 roku w Warszawie. Do pierwotnego składu towarzystwa należeli między innymi Mieczysław Rulikowski (pierwszy prezes), Edward Chwalewik (twórca statusu), Adam Półtawski (grafik, autor godła TBP), Stanisław Piotr Koczorowski (kustosz Biblioteki Polskiej w Paryżu), Ludwik Bernacki (dyrektor Zakładu Narodowego im. Ossolińskich we Lwowie). W 1948 roku Towarzystwo zostało rozwiązane, ale już w 1957 roku powołano Towarzystwo Przyjaciół Książki (między innymi Julian Krzyżanowski, Juliusz Wiktor Gomulicki, Mieczysław Brahmer, Aleksander Birkenmajer), które istniało do 2001 roku. W 2004 roku reaktywowano Towarzystwo Bibliofilów Polskich (prezes prof. Edward Towpik) — dane na podstawie oficjalnej strony TBP: http://bibliofile.org.pl/historia/ [dostęp: 10.07.2018].

${ }^{14}$ Idea książki pięknej (book beautiful) odrodziła się w dziewiętnastowiecznej Anglii za sprawą Williama Morrisa i założonego przez artystę wydawnictwa Kelmscott Press. W Polsce zwiastuny propagowania tej idei odnajdujemy na przełomie XIX i XX wieku, ale szeroko rozwinęła się ona dopiero $\mathrm{w}$ dwudziestoleciu międzywojennym, między innymi dzięki działaniom Towarzystwa Bibliofilów Polskich; na ten temat por. między innymi J. Bajda, „Poeci - to sa stów malarze...” Typy relacji między stowem a obrazem w ksiązkach poetyckich Młodej Polski, Wrocław 2010, s. 391-426 (cz. 4. Książka piękna; tu także obszerna literatura przedmiotu). 
czyzna, na którą szczególną uwagę zwraca w swojej nocie Anna Mickiewicz), ale pamięć filtrowaną przez momentalny zachwyt spojrzenia napotykającego kamienny relief czy pojedynczą barwną plamę. To owo szerokie studium, na którego tle stają się możliwe jednorazowe zderzenia z nienazwanym punctum.

Na podstawie wierszy Ledóchowskiego nie da się stworzyć katalogu powszechnie uznawanych za wybitne dzieł sztuki polskiej czy europejskiej. Poeta zgromadził niewielkie prywatne archiwum, swoiste musée imaginaire wypełnione różnorakimi tesserami, z których dopiero z perspektywy lat można próbować stworzyć mozaikę jego artystycznych preferencji, dzieł, które go poruszyły i których nie odbierał jedynie w granicach kulturowego, ,grzecznego”, jak o nim pisze Barthes ${ }^{15}$, studium.

\section{Architektura}

Odniesienia do konkretnych budowli pojawiają się w wierszach Ledóchowskiego zaledwie kilkakrotnie, ale ich walor historyczny i estetyczny jest ściśle określony: poetę interesuje architektura gotycka, a szczególnie średniowieczne świątynie. Najbliższe są mu kościoły krakowskie. Wiersz Katedra na Wawelu ${ }^{16}$ wprowadza elementy klasycznej ekfrazy, wiodąc czytelnika przez wnętrze świątyni, wydobywając architektoniczne i rzeźbiarskie detale, uwrażliwiając na działanie światła wpadającego przez witrażowe szkła i ślizgającego się po zróżnicowanych fakturach. Na istotę tak rozumianej periegezy po architektonicznych monumentach zwracają uwagę badacze, podkreślając chęć oddania wielkości, dostojeństwa, siły budowli ${ }^{17}$. Jednak w wierszu Ledóchowskiego nie odczuwa się tej niedostępności gotyckiej przestrzeni, lęku przed jej wzniosłością czy potęgą odmierzaną kolejnymi stuleciami. To wychwytywanie konkretnych artefaktów (kamienne stopnie, sarkofagi, trumna), dostrzeganie wybranych motywów naściennego malarstwa (korona), odnotowywanie architektonicznego detalu konstrukcji (ostrołuki) czy zróżnicowanej faktury materii (miedź, kamień). Ale nie tylko, bo za każdym razem elementy te znaczone są siłą pamięci historii i tożsamości miejsca:

W ostrołukach koronę Kazimierza malarz Jan cierpliwie malował,

miedzianym wiekiem zamknięto szmat ziemi, tyleż cierpień, uśmiechy dziecka.

$[\ldots]$

15 „Niestety, wiele zdjęć nie ożywa pod moim spojrzeniem. A nawet większość z tych, które jakoś dla mnie istnieją, działa na mnie tylko ogólnie i, jeśli tak można powiedzieć, grzecznie; nie ma w nich żadnego punctum. Podobają mi się lub nie, lecz nic we mnie nie wywołują: mają w sobie jedynie studium", por. R. Barthes, op. cit., s. 52.

${ }^{16}$ S. Ledóchowski, Katedra na Wawelu, [w:] idem, Liście od Krakowa, s. 5-6.

17 Por. M. Czermińska, Gotyk i pisarze. Topika opisu katedry, Gdańsk 2003, s. 37 n. 
Głaz oprze się czasowi,

lecz nigdy naszej stopie,

stopnie katedry drążymy sumiennie -

stulecie po stuleciu, epoka po epoce ${ }^{18}$.

Katedra dla Ledóchowskiego to nie jedynie mury. Tym, co przemawia, są czas i przestrzeń wyznaczane kamiennymi granicami. A tych nie da się rozpoznać jedynie zmysłem wzroku. Dlatego architektury się dotyka, a ostatecznie, żeby w pełni poddać się działaniu jej potęgi, wsłuchuje się w nią, w jej milczenie i ciszę (miejsca?, danej chwili?, przeszłości? ${ }^{19}$. To ona jest dla poety tym niepowtarzalnym poruszeniem:

Cisza jest w mroku odmierzającym czas uzurpatorom na udrapowanych transparentem tronach, sarkofagom strzegącym pamięci królów, krwi zmytej z ulicznego bruku ${ }^{20}$.

Inaczej spotyka się Ledóchowski z wielkimi katedrami Francji ${ }^{21}$. Wiersz wydany $\mathrm{w}$ formie bibliofilskiego druku został poprzedzony odautorską notą zamkniętą w wizualnym kształcie strzelistego hełmu gotyckiej wieży, w którym autor odsłania podziw dla średniowiecznych budowli i ich twórców:

KATEDRY FRANCJI

to niezwykłe zjawisko

o jednorodnym programie

decorum i sacrum.

Powstające na przełomie

romańskiej gotyckiej sztuki

świątynie,

znalazły swój ostateczny wyraz

w profuzji płomienistego gotyku, tworząc widnokrąg

D Z I E J Ó W Z B A W I E N I A.

Ogrom prac przerastał jednak możliwości jednego pokolenia,

toteż żaden z kolejnych muratorów nie uczestniczył w ukoronowaniu dzieła.

A własne signum pozostawili ich kontynuatorzy

jeszcze w dziewiętnastym stuleciu,

chociażby w postaci chimer Viollet-le-Duca

na szczycie katedry Notre-Dame w Paryżu, skąd przeszłość staje się jedną z odsłon teraźniejszości22.

18 S. Ledóchowski, Katedra na Wawelu.

${ }^{19}$ Kwestię znaczenia szerokiego odbioru architektury w kontekście jej opisu podejmuje Wojciech Bałus w artykule Architektura - czlowiek - język. Od ciała do słowa, [w:] Literatura a architektura, red. J. Godlewicz-Adamiec, T. Szybisty, Kraków-Warszawa 2017, s. 21-34.

${ }^{20}$ S. Ledóchowski, Katedra na Wawelu.

${ }^{21}$ S. Ledóchowski, Katedry Francji, Warszawa [b.d.w.].

22 S. Ledóchowski, Nota odautorska, [w:] ibidem. 
Także strofy wiersza to niemalże sekretne spotkanie z mistrzostwem ludzi wieków średnich, hommage składany pokoleniom bezimiennych muratorów, snycerzy, szklarzy czy kowali. Rzadko w wierszach o sztuce w sposób tak jednoznaczny wskazuje się na podmiot sprawczy dzieła, szczególnie równie anonimowy jak średniowieczni budowniczy. To jeden z tych utworów, w których ujawnia się Ledóchowski artysta chylący głowę przed potęgą sztuki, choć daleki od modernistycznych mrzonek o istnieniu dzieła dla niego samego. Dosłowna wielkość katedry w Amiens to przede wszystkim wielkość twórców „murów, sklepien, zworników, witraży", modlitwa składana przez ich pracę:

Pochylam czoło pośród cieni katedr,

modląc się za dzwonników dłonie,

za serca dzwonów, za organy Amiens...

Ora pro nobis.

Amen.

Wieże katedry noce wydłużyły -

doprowadziły do nieba

granatowego, brzmiącego chmurami

w instrumentach Beethovena...

Ave sanctissima.

Wielka przyjaciółko bezimiennych muratorów,

snycerzy, szklarzy, kowali,

wybacz jeśli o zmierzchu dnia

zamiast modlić się śpiewali...

Kowal galerą przybył z morza minaretów, rzeźbiarz w lochu pojął muzykę kamienia.

Zamknęło się niebo za śpiewającymi...

Ora pro nobis.

Mea culpa.

Jeszcze ich słyszę w szmerach murów,

sklepień, zworników, witraży,

idę za cieniami niknącymi w nawie,

przywołującymi mnie bezrozumnym gwarem...

Z żalu odlatujących o świcie żurawi,

$\mathrm{z}$ łez wdeptanych $w$ jesienne liście,

daninę składam narzędziom w dłoni.

Ora pro nobis.

Kyrie $^{23}$.

Nie odczuwa się tu ani potrzeby mimetycznej wierności wobec opisywanej architektury, ani konieczności stosowania chwytów ułatwiających odbiorcy jej unaocznienie, o które dopominali się przedstawiciele drugiej retoryki, definiując

23 S. Ledóchowski, Katedry Francji. 
ekfrazę $^{24}$. Nie ma mowy o rywalizacji między siostrzanymi sztukami. Słowo nie staje przed wymogiem „dorównania” oryginalnemu dziełu, a daje jego poetycką transpozycję, jest dopełnieniem miejsc niedookreślonych ${ }^{25}$, wydobywając z cienia sens anonimowości budowniczych i istotę pozostawiania pojedynczych śladów muratorów, ludwisarzy czy rzeźbiarzy, które przez kolejne pokolenia zdołały urosnąc do potęgi katedry.

\section{Rzeźba}

Przestrzenią, do której chętnie powraca Stanisław Ledóchowski podczas swoich wędrówek po Krakowie, jest kościół Mariacki²6, choć w zasadzie raz jeden można mówić o nawiązaniu do konkretnych dzieł rzeźbiarskich znajdujących się w bazylice i to też — w sposób jedynie pośredni. W wierszu Modlitwa Wita Stwosza nie zaistniał sam ołtarz. Po raz kolejny bohaterem czyni poeta nie tyle namacalne dzieło, ile jego twórcę. Monolog norymberskiego mistrza kierowany do figur ołtarzowego retabulum przeradza się w intymną rozmowę pełną czułości, a jednocześnie wyrzutów i twórczej niepewności efektów własnej pracy:

Rzeźby moje, kiedyś z lipowego drzewa,

dziś z zapamiętania utraconego spojrzenia.

Twory niekończących się nocy, niezaczętych dni, niezaspokojonych dłoni, porzuconych myśli...

$[\ldots]$

Krąg wasz wykreśla niebotyczną tęczą

exodus cieni, bez celu i treści.

Słuchajcie przyjaciele - pielgrzymi odwieczni:

teraz, kiedy święci z ołtarza zawiedli,

pozostały po was tylko wspomnienia i żale,

rzeźby moje - jedyne Wita ukochanie $[\ldots]^{27}$.

${ }^{24}$ Remigiusz Popowski (op. cit., s. 34-35) wymienia główne cechy starożytnej ekfrazy: „Do pożądanych zalet ekfrazy zaliczają się saphéneia — 'jasność, dokładność, wyrazistość' i enárgeia — 'namacalność, realność, żywość przedstawienia'. Przymioty te oznaczane są również słowami diatýposis ('wyrazistość, żywość przedstawienia'), hýpotiposis ('obrazowość przedstawienia') lub łacińskim terminem evidentia, który Kwintylian [...] uważa za figurę retoryczną i dzięki któremu retor unaocznia i uszczegóławia, tak że słuchacze nie tyle słyszą, ile raczej widzą to, o czym rozprawia [...]".

${ }^{25}$ Nie jest to nowe myślenie o wzajemnych relacjach między różnymi dziedzinami sztuk. Odwołując się do kwestii tłumaczenia intersemiotycznego i intertekstualnych kontekstów, o typach wzajemnych powinowactw i dookreślania się przez różne dziedziny sztuki pisali przed laty w kanonicznych już dziś tekstach między innymi (chronologicznie): E. Balcerzan, Poezja jako semiotyka sztuki, [w:] Pogranicza i korespondencje sztuk, red. T. Cieślikowska, J. Sławiński, Wrocław 1980, s. 21-39; A. Kowalczykowa, O wzajemnym oświetlaniu się sztuk w romantyzmie, [w:] ibidem, s. 177-191; S. Wysłouch, Literatura a sztuki wizualne, Warszawa 1994; eadem, Literatura i semiotyka, Warszawa 2001.

${ }^{26}$ S. Ledóchowski, Litania; Pasterka w Kościele Mariackim, [w:] idem, Liście od Krakowa, s. 8,9 .

${ }^{27}$ S. Ledóchowski, Modlitwa Wita Stwosza, [w:] ibidem, s. 7. 
Lęk przed materią twórczą, ale też wątpliwości co do ostatecznego kształtu własnego dzieła (bez względu na uprawianą dziedzinę) i pozostawianego w nim przesłania są stałymi motywami poezji. Sięgali po nie najwięksi, począwszy od Horacego ${ }^{28}$, przez Michała Anioła opisującego fizyczny trud mierzenia się ze złomami karraryjskiego marmuru i freskami w kaplicy Sykstyńskiej ${ }^{29}$, po poetów nam bliższych, jak Leopold Staff, który wielokrotnie powracał do myśli „dziwacznego tumu"30. Tylko nieco wcześniej Stéphane Mallarmé pisał wprost o nocach spędzanych „Nad pustą kartą, której strzeże biel okrutna”31. Do tych wszystkich niepokojów i rozterek twórczych nawiązuje też Stanisław Ledóchowski. Nie dziwi, że odpowiedzi szuka właśnie pośród dzieł rzeźbiarskich — materii i form mu najbliższych, które rozpoznawał nie tylko jako widz, stając przed retabulum Stwosza, lecz przede wszystkim jako praktyk, którego dłonie na zawsze (parafrazując linijki wiersza) zapamiętały utrwalany w rzeźbiarskim tworzywie kształt. Spotkanie z figurami rytymi w lipowych klocach staje się dla poety spotkaniem z samym sobą, chwilami, które powracają w jednej ze strof:

Rzeźby moje, niewdzięczne boginie -

gdzie jesteście ciała niezniszczone,

kształty w strzępy podarte,

w palcach pamiętliwe? $?^{32}$

Część tych pytań trzeba pozostawić bez odpowiedzi. Nie wszystko musi zostać rozpoznane i nazwane. Nawet nie powinno, bo wówczas nagle przestaje znaczyć, oddziaływać, poruszać. „To, co mogę nazwać, nie może mnie w rzeczywistości uderzyć" ${ }^{33}$, pisał Barthes. I tak też spotyka się z dziełem sztuki Stanisław Ledóchowski. Wie, że chce się przed nim zatrzymać, ale to dla siebie pozostawia odpowiedź na pytanie: dlaczego właśnie tu?

Podobnie jak w zderzeniu polskiej i francuskiej architektury gotyckiej Ledóchowski zestawia w swojej twórczości monumentalne retabulum Stwosza z dziełem obcym, tym razem - skromną wczesnośredniowieczną figurą Chrystusa Dobrego Pasterza z bazyliki św. Klemensa na Lateranie w Rzymie. Bibliofilskie wydanie wiersza Pastore con pecore ${ }^{34}$ zostało opatrzone przez autora kolejną osobistą notą, w której znajdujemy nie tylko zachwyt samym dziełem, ale też poetycką pokorę wobec niewyrażalnego: „Nie znam dzieła sztuki — pisze Ledó-

28 Por. Horacy, Dwadzieścia dwie ody, przeł. A. Ważyk, oprac. S. Stabryła, Wrocław 1991.

${ }^{29}$ Por. L. Staff, Michat Aniot i jego poezje, przekł. poezji L. Staff, wybór i wstęp M. Brahmer, Warszawa 1977.

${ }^{30}$ Por. wiersze Leopolda Staffa zawarte w pierwszym tomie jego poezji Sny o potędze (1901), między innymi Kowal, dziwaczny tum, Sen nieurodzony.

${ }^{31}$ S. Mallarmé, Wiatr morski [oryg. Brise marine], przeł. R. Matuszewski, [w:] J. Lisowski, Antologia poezji francuskiej, t. 3, Warszawa 2000, s. 561.

32 S. Ledóchowski, Modlitwa Wita Stwosza. Pierwszoosobowy podmiot artysty rzeźbiarza powraca też w wierszu Ledóchowskiego Jan Marcin Świeboda (Liście od Krakowa, s. 10).

33 R. Barthes, op. cit., s. 96.

${ }^{34}$ S. Ledóchowski, Pastore con pecore, Warszawa [b.d.w.]. 
chowski - o podobnej wymowie i sile wyrazu, dlatego też nie wiem, czy poetyckie słowo może sprostać takiemu wyzwaniu" 35 . Nie pierwsze to poddanie pióra wobec siły wizualnego przekazu, a historia literatury odnotowuje liczne deklaracje zarówno polskich, jak i obcych pisarzy o zamilknięcia słowa i oddaniu pierwszeństwa obrazowi ${ }^{36}$. Z próby linearnego opisu marmurowej postaci Chrystusa rezygnuje też Stanisław Ledóchowski, wpisując ją najpierw w mocno zarysowane martyrologiczne wątki minionych stuleci, żeby następnie wskazać jej zdecydowanie nadrzędną, uniwersalną wymowę. To chwyt często wprowadzany w utworach o charakterze ekfrastycznym (żeby powołać się chociażby na Homerowy opis tarczy Achillesa), pozwalający na pewną fabularyzację momentu ujętego na płótnie czy - jak w tym przypadku - utrwalonego w kamieniu. Charakteryzujące ekfrazę wyznaczniki obcowania $\mathrm{z}$ realnym dziełem zostały wprowadzone w wierszu także poprzez trzy zasadnicze elementy ikonograficzne umożliwiające jednoznaczną identyfikację rzeźby. Pierwszym z metatekstowych odniesień jest tytuł utworu Pastore con pecore ${ }^{37}$. Ostateczne utożsamienie następuje w drugiej strofie przez wprowadzenie do wiersza miejsca przechowywania rzeźby (laterańska bazylika św. Klemensa) oraz zastąpienie opisowego wyszczególnienia jej cech metaforycznym ujęciem okaleczonego przez stulecia ciała (posągowi brakuje części nóg i rąk) i wznoszonych ku górze półprzymkniętych oczu:

Przeszedł okrąg Ziemi, rampy obozów, stopnie tronów, gilotyn, katowni. Bruk ranił, szyny spowijały nogi, stopy parzył popiół krematoriów.

W Bazylice San Clemente udręczone ciało oparł o próg, gestem utraconych dłoni wzrok gasnący wznosi do Ojca z ufnością się modli.

35 S. Ledóchowski, Wyznanie, [w:] ibidem.

36 Por. na przykład A. Mickiewicz, Pan Tadeusz, ks. XII (Kochajmy się), w. 427-434 (tu opis urody Telimeny); J. Słowacki, Podróż do Ziemi Świętej z Neapolu, [w:] idem, Dzieła wybrane, Wrocław 1987, t. 2, s. 55-57 (tu opis klasztoru Megaspilion); J. Verne, Vingt mille lieues sous les mers, Paris 1971, s. 145 (tu opis morza); J.-M. Villiers de l'Isle-Adam, Tribulat Bonhomet, [w:] Oeuvres complètes, Paris 1986, t. I.2, s. 219 (rozdz. 20 [1867]) (tu opis obrazu). Na ten temat por. J. Bajda, op. cit., s. 57-70 (rozdz. I.6. Poetyckie myślenie obrazami; tu także literatura przedmiotu).

37 Częściej spotyka się w ikonografii określenie tego typu przedstawienia jako Dobrego Pasterza (Pastor bonus, J, 10,11). Typ ten — jako jeden z symboli idei zbawienia — został wprowadzony do ikonografii chrześcijańskiej bardzo wcześnie, bo już w II wieku. Zabytki sztuki wczesnochrześcijańskiej i średniowiecznej, do której zalicza się także rzeźba z bazyliki św. Klemensa, oddają Chrystusa zazwyczaj jako młodzieńca odzianego w tunikę, na którego barkach leży trzymana przez niego owca. Por. na przykład Pasterz, [hasło w:] D. Fouilloux et al., Kultura biblijna. Stownik, przeł. M. Żurowska, Warszawa 1997, s. 193; H. Biedermann, Pasterz, [hasło w:] idem, Leksykon symboli, przeł. J. Rubinowicz, Warszawa 2003, s. 268. 
Pójdzie, gdy zabliźni rany,

szukać owczarni swojej,

w miłości i ofiarnym trwaniu

niepojęty ${ }^{38}$.

To przykład dzieła poruszającego odbiorcę poprzez „brak”, „pustkę”, które stają się jego niezbędnym dopełnieniem, przynależą do niego i działają silniej niż jakiekolwiek dopowiedzenie. I choć czytamy o zabliźnianiu się ran, to nikt nie myśli o rekonstrukcji nieobecnego — Chrystusowych ramion, na których spoczywała ufna owca ${ }^{39}$.

\section{Malarstwo}

Obrazy pojawiają się w wierszach Stanisława Ledóchowskiego najrzadziej, bo zalewie dwa razy i jedynie w bibliofilskich wydaniach jego utworów. W obu przypadkach są to dzieła obce. Pierwszym z nich jest słynne płótno Thomasa Gainsborough Btękitny chtopiec. Poetycka interpretacja Ledóchowskiego to jeden z jego najbardziej plastycznych wierszy. Kilkoma pociągnięciami słowa wprowadza do opisu klimat angielskiego parku, przewodnią barwę płótna, sugestię niepewności chwili zmierzchu, nonszalancję pozy modela, a równocześnie mistrzowskie oddanie charakteru stroju młodzieńca znaczonego giętkimi liniami błękitnego jedwabiu, wstążek i piór. Kontrastuje z tą niemalże rokokową afektacją intensywny i niepokojący wężowy szpaler szmaragdowych drzew odbijających się w drapieżnym zwierciadle nieba. Pojawia się też, jak zawsze ważny dla Ledóchowskiego, sam autor mającego dopiero powstać arcydzieła:

\footnotetext{
Nad starym parkiem zapada zmierzch, przywołując tęsknotę i marzenia...

Jutro zaczniesz swój nowy, szczęśliwy dzień, cały w błękitach, wstążkach i piórach.

Szmaragdowych szpalerów wąż długi przegląda się w zwierciadle nieba, na ścieżkach kładzie się chybotliwy cień to Gainsborough niesie sztalugi ${ }^{40}$.
}

${ }^{38}$ S. Ledóchowski, Pastore con pecore.

${ }^{39}$ Buon Pastore z kościoła św. Klemensa w Rzymie to nie jedyny przykład dzieła, które oddziałuje na odbiorcę właśnie przez „brak”. Przypomnijmy chociażby Nike z Samotraki, której nieistniejące ramiona przywoływali w wierszach między innymi: Maria Pawlikowska-Jasnorzewska (Nike, [w:] Pocałunki, 1926); Antoni Słonimski (Nike, „Skamander” 1939); Leopold Staff (Nike z Samotraki, [w:] Martwa pogoda, 1946); Zbigniew Herbert (Nike, która się waha, [w:] Struna światta, 1956).

${ }^{40}$ S. Ledóchowski, Btękitny chłopiec, Warszawa [b.d.w.]. 
Ostatnia strofa sugeruje powód poetyckiej próby zmierzenia się z portretem, choć wcale go nie precyzuje. „Zachwyt” pozostaje ostatecznie w sferze niedopowiedzenia i „,ciszy” (jak w wypadku krakowskiej katedry):

Pozostaniesz w ciszy nieodgadnionego spojrzenia,

w oddaleniu, gdzie pogłos kroków Twoich ginie,

a w thumie oniemiały z zachwytu Polak,

co wiersze pisze ${ }^{41}$.

Drugie z wyróżnionych przez Ledóchowskiego słowem dzieł malarskich mieści się w kręgu zainteresowań autora sztuką dawną — wieków średnich i doby włoskiego odrodzenia. Jest nim Zwiastowanie Simone Martiniego, powstałe przy współpracy z Lippo Memmim w 1333 roku dla katedry sieneńskiej, a obecnie znajdujące się we florenckiej Galleria degli Uffizi. Pośród bibliofilskich wydań wierszy Ledóchowskiego druk wyróżnia się szczególną dbałością o formę, począwszy od okładki, na której znalazła się renesansowa drzeworytnicza bordiura, przez umieszczenie na osobnej karcie reprodukcji fragmentu dzieła Martiniego ${ }^{42}$, aż po wykorzystanie szesnastowiecznego liternictwa inicjującego kolejne strofy.

Choć wprowadzone w tytule i pierwszych linijkach wiersza metatekstowe sygnały w postaci miana dzieła, nazwiska malarza, daty i miejsca powstania ołtarza od razu odsyłają do konkretnego przedstawienia, czytelnik szybko orientuje się, że są to strofy, które nie opisują, lecz stają się spotkaniem poety z innym twórcą, malarzem, człowiekiem. Podziwiane arcydzieło sieneńczyka właściwie w ogóle nie zaistniało w tym utworze (podobnie jak ołtarzowe retabulum Wita Stwosza). Rok jego powstania jest istotny, ale bardziej dlatego, że to niemal pięćdziesiąty rok życia Martiniego, a jedenasty przed jego śmiercią. Ważne jest też miejsce, ale nie wskazuje Ledóchowski sieneńskiej katedry, dla której powstał ołtarz, a samo miasto, umieszczając je na mapie pereł włoskiej urbanistyki:

W roku tysiąc trzysta trzydziestym trzecim prawie pięćdziesięcioletni Simone Martini, na jedenaście lat przed śmiercią, stworzył dzieło swojego życia

$\mathrm{Z}$ wi a s tow a n i e.

Ave Sanctissima

A oto Siena, na drodze z Rzymu do Florencji, gdzie Archanioł Gabriel zwiastował Marii w złotym ostrołuków opromieniowaniu, jak organy wznoszącym słowa nadziei w godzinę wesela.

Ave Maria gratia plena ${ }^{43}$.

${ }^{41}$ Ibidem.

${ }^{42}$ Reprodukcje dzieł (całości bądź ich fragmentów) znajdują się we wszystkich bibliofilskich wydaniach wierszy Ledóchowskiego i są nieodzownym elementem tych akcydensowych druków.

${ }^{43}$ S. Ledóchowski, Zwiastowanie, Warszawa [b.d.w.]. 
Te wyznaczniki ekfrastyczności wiersza pojawiają się niemal mimochodem jako kulturowe studium świadczące o erudycji i świadomości estetycznej autora. Równocześnie jednak tworzą tło słów o dziele życia i chwili, o której nigdy się nie wie, że jest tą najważniejszą. Nagle okazują się absurdalnie płoche w porównaniu z prostym faktem spotkania dwojga ludzi, dzięki czemu obraz mógł zaistnieć:

\footnotetext{
Szymonie, synu Marcina, przyjacielu Petrarki, jak spotkałeś oblubienicę, co mogła być świętą lub w Twoich dłoniach partyturą uległą?

Gdzieś malował i o jakiej porze stanąłeś na progu zachwycenia, oczekiwania na przyzwanie lub gest odtrącenia? ${ }^{44}$

O więcej nie może pytać nawet słowo poety:

Nie pytam o więcej: o imię i ślady, wtedy zadąsanej, powabnej dziewczyny, dziś przyjmującej zwiastowanie $\mathrm{M}$ a r i i. Angelus Domini nuntiavit Mariae.
}

\section{Spotkania ze sztuką}

Wiersze Stanisława Ledóchowskiego, w których pojawiają się odwołania do dzieł sztuki, nie są „modelowymi” czy „właściwymi” ekfrazami ${ }^{45}$ w ich klasycznej definicji, choć występują w nich liczne elementy konstytutywne dla tego gatunku. Ledóchowski nie ucieka od przyznawania się do określonych fascynacji artystycznych, wprowadza do tytułów swoich wierszy nazwy dzieł, wymienia nazwiska ich twórców, niekiedy dookreśla miejsce ich powstania, przechowywania czy po prostu istnienia (jak w wypadku budowli architektonicznych), w wydaniach bibliofilskich swoich wierszy zawsze umieszcza reprodukcję dzieła. Te metatekstowe nawiązania są jednoznacznym świadectwem znaczenia konkretnego artefaktu dla poety, dokonywania świadomych wyborów. Nie ma w tych wierszach narracyjnych tematów mitologicznych i przypowieści biblijnych — od stuleci miejsc wspólnych dla poezji i malarstwa. Nie ma też precyzyjnych opisów pozwalających na unaocznienie dzieła. Ledóchowski szuka w dziele sztuki pretekstu do rozważań ideowych, światopoglądowych, egzystencjalnych. Nie wprowadza ich jednak przez fabularyzację utrwalonego w dziele momentu, rezygnując z charakterystycznych dla ekfraz rozległych narracji retrospektywnych i antycypacyjnych $w$ stosunku do utrwalonej w dziele sceny. Wprawdzie rozbija jedność widzenia dzieła, ale nie przez snucie wokół niego historii, a wprowadzanie do interpretacji elementu kreacji, działania, czynnika sprawczego. Rozważa go, zadaje pytania, poprzez dzieło przypomina jego twórcę. Jeżeli skupia się na detalu,

44 Ibidem.

45 Pojęcia za: P. Gogler, op. cit., s. 141. 
to paradoksalnie są to najczęściej szczegóły, które odnoszą się do „ułomności”, „braku”, „,niedostatku” czy „ulotności”: ubytki romańskiej rzeźby, zniszczone kamienne stopnie żłobione przez stulecia stopami pielgrzymów, anonimowość portretowanej dziewczyny, cisza katedralnego wnętrza, drżący cień nieobecnego malarza. Fizyczny brak konkretu nie oznacza jednak braku w dziele jego subtelnego śladu. Zostanie ono przepisane słowem wówczas, gdy poeta dostrzeże w nim to jedyne i niepowtarzalne miejsce spotkania $z$ drugim człowiekiem, owo niemalże niewidoczne punctum odsyłające daleko poza samo dzieło. To tylko dzięki niemu rzeźba czy obraz każą się przed sobą zatrzymać i wstrzymać oddech.

\section{Bibliografia}

Bajda J., „,Poeci - to są stów malarze...” Typy relacji między stowem a obrazem w książkach poetyckich Młodej Polski, Wrocław 2010.

Balcerzan E., Poezja jako semiotyka sztuki, [w:] Pogranicza i korespondencje sztuk, red. T. Cieślikowska, J. Sławiński, Wrocław 1980, s. 21-39.

Bałus W., Architektura - czlowiek - język. Od ciała do słowa, [w:] Literatura a architektura, red. J. Godlewicz-Adamiec, T. Szybisty, Kraków-Warszawa 2017, s. 21-34.

Barthes R., Światto obrazu. Uwagi o fotografii, przeł. J. Trznadel, Warszawa 2008.

Biedermann H., Leksykon symboli, przeł. J. Rubinowicz, Warszawa 2003.

Cieślak R., Oko poety. Poezja Tadeusza Różewicza wobec sztuk wizualnych, Gdańsk 1999.

Czermińska M., Ekfrazy w poezji Wisławy Szymborskiej, „Teksty Drugie” 2003, nr 2-3, s. 230-242.

Czermińska M., Gotyk i pisarze. Topika opisu katedry, Gdańsk 2003.

Dziadek A., Obraz jako interpretant. Na przykładzie polskiej poezji wspótczesnej, „Pamiętnik Literacki" 92, 2001, z. 2, s. 127-148.

Dziadek A., Obrazy $i$ wiersze. Z zagadnień interferencji sztuk w polskiej poezji współczesnej, Katowice 2004.

Dziadek A., Problem Ekphrasis - dwa Widoki Delft (Adam Czerniawski i Adam Zagajewski), „Teksty Drugie” 2000, z. 4 (63), s. 141-152.

Filostrat Starszy, Obrazy, przekł., kom. i przyp. R. Popowski, Warszawa 2004.

Fouilloux D. et al., Kultura biblijna. Stownik, przeł. M. Żurowska, Warszawa 1997.

Gogler P., Kłopoty z ekfraza, „Przestrzenie Teorii” 2004, nr 3-4, s. 137-152.

Grodecka A., Wiersze o obrazach. Studium z dziejów ekfrazy, Poznań 2009.

Grodecka A., Stowo i obraz w epoce multiplikacji, Poznań 2016.

Horacy, Dwadzieścia dwie ody, przeł. A. Ważyk, oprac. S. Stabryła, BN II, nr 232, Wrocław 1991.

Interakcja sztuk: literatura, malarstwo, ekfraza, red. D. Heck, Wrocław 2008.

Kowalczykowa A., O wzajemnym oświetlaniu się sztuk w romantyzmie, [w:] Pogranicza i korespondencje sztuk, red. T. Cieślikowska, J. Sławiński, Wrocław 1980, s. 177-191.

Ledóchowski S., Błękitny chłopiec, Warszawa [b.d.w.].

Ledóchowski S., Katedry Francji, Warszawa [b.d.w.].

Ledóchowski S., Liście od Krakowa, Warszawa 2013.

Ledóchowski S., Pastore con pecore, Warszawa [b.d.w.].

Ledóchowski S., Zwiastowanie, Warszawa [b.d.w.].

Łukasiewicz J., Grochowiak i obrazy, Wrocław 2002.

Markowski M.P., Ekphrasis. Uwagi bibliograficzne z dołaczeniem krótkiego komentarza, „Pamiętnik Literacki" 90, 1999, z. 2, s. 229-236.

Mickiewicz A.M., Stanisław Ledóchowski, [w:] D. Błaszak, A.M. Mickiewicz, Kosmos literatów, Orlando 2018, s. 249-250. 
Popowski R., Wstęp, [w:] Filostrat Starszy, Obrazy, przekł., kom. i przyp. R. Popowski, Warszawa 2004, s. 13-88.

Skwara M., O niektórych właściwościach ekfrazy. Na przykładzie poetyckich recepcji Szału uniesień Władystawa Podkowińskiego w wybranych utworach młodopolskich i nie tylko, [w:] Perspektywy polskiej retoryki, red. B. Sobczak, H. Zgółkowa, Poznań 2007, s. 192-210.

Staff L., Michat Anioł i jego poezje, przekł. poezji L. Staff, wybór i wstęp M. Brahmer, Warszawa 1977.

Wysłouch S., Literatura a sztuki wizualne, Warszawa 1994.

Wysłouch S., Literatura i semiotyka, Warszawa 2001.

\section{Between studium and punctum: Encounters with art in the poetic works of Stanisław Ledóchowski}

\section{Summary}

This article discusses ekphrases of the poet, sculptor, stage designer, and art critic Stanisław Ledóchowski, which were published in 2013 in his volume of poetry Liście od Krakowa and in several bibliophile editions of his individual works.

The discussion concerns poems dealing with three forms of art: architecture, sculpture, and painting. Poetic interpretations of works of art were placed in the context of the terms studium and punctum introduced by Roland Barthes to describe the method of finding meaning in art on two levels. The studium concerns generally available cultural context, while the punctum is an often-intimate encounter of the viewer with an artistic work, which not only reveals the specific aesthetic awareness of the poet but also his individual sensitivity.

Keywords: Stanisław Ledóchowski, ekphrasis, Roland Barthes, studium, punctum, architecture, sculpture, painting 